\title{
PELAKSANAAN PUTUSAN NAFKAH ISTRI PASCA CERAI TALAK DI PENGADILAN AGAMA PAMEKASAN
}

\author{
Eka Susylawati, Moh. Masyhur Abadi, \\ dan H. M. Latief Mahmud \\ (Sekolah Tinggi Agama Islam Negeri Pamekasan, jln. Pahlawan KM. 04, email: \\ Eks@yahoo.com)
}

\begin{abstract}
Abstrak
Pada umumnya dalam perkara cerai talak selain memutus perkara pokoknya, pengadilan agama juga mewajibkan untuk membayar nafkah pada istri dan anak. Hal ini ternyata berbeda dengan penerapan putusan, karena pemenuhan kewajiban suami tidak selamanya berjalan baik. Pada sebagian perkara pasca perceraian, istri tidak mendapatkan nafkah walaupun hal tersebut sudah diputus oleh pengadilan. Karenanya, ada 2 (dua) fokus dalam kajian ini, yakni bagaimana pelaksanaan putusan nafkah istri pasca putusan cerai talak di Pengadilan Agama Pamekasan dan bagaimana penyelesaian jika nafkah tidak dilaksanakan. Hasil penelitian menunjukkan bahwa pelaksanaan nafkah istri pasca cerai talak di Pengadilan Agama Pamekasan diakumulasi dengan tuntutan lain, misalnya harta bersama dan perwalian anak. Sebagian suami membayar nafkah sebelum melakukan ikrar talak. Majelis hakim akan menunda pelaksanaan ikrar talak bagi suami yang belum membayar nafkah kepada istri sampai 6 bulan. Namun, jika dalam 6 bulan tidak dapat direalisasikan, maka secara yuridis pengadilan agama tidak dapat menghalangi suami untuk mengucapkan ikrar talak, walaupun belum membayar nafkah kepada istri.
\end{abstract}

\footnotetext{
Abstract

Divorce cases commonly decide not only the main cases but a religious court also obligates to pay the living cost for the wives and children. But the fact is different with its implementation since the fullfilment of husbands' obligation does not always run well. For some cases after the divorce, the wives do not get the living cost although the cases have been decided by the religious court. Therefore, there are two
} 
research focuses in this study. First, how the implementation of wives' living cost after the decision of divorce in the religious court of Pamekasan. Second, how the settlement if the living cost have not been implemented. The results of the research show that the implementation of the wives' living cost after divorce in the Religious Court of Pamekasan is accumulated with other demands, such as common property and children guardianship. Some husbands give the living cost before saying the pledge of divorce. The judges will postpone the implementation of the divorce for the husbands who have not paid their wives' living cost for six months. However, if within 6 months they cannot pay it so in a formal sense, the religious court cannot keep the husbands from saying the divorce pledge although they have not paid their wives' living cost.

\section{Kata-kata Kunci}

Nafkah istri, cerai talak, ikrar talak, pengadilan agama, eksekusi.

\section{Pendahuluan}

Perkawinan merupakan masalah keluarga yang sangat menentukan dalam suatu masyarakat. Apabila dalam suatu negara masalah perkawinan tidak diatur dalam aturan hukum, maka akan menyebabkan masyarakat akan tidak teratur karena kondisi keluarga sangatlah mempengaruhi kondisi masyarakat secara luas.

Lembaga perkawinan merupakan dasar peradaban umat manusia dan tempat bagi manusia untuk mengabadikan diri satu sama lain dan saling menghormati perasaan pasangannya. Perkawinan merupakan suatu kejadian yang sangat penting dalam kehidupan seseorang. Ikatan perkawinan ini menimbulkan akibat hukum terhadap suami istri maupun berupa hubungan hukum berupa hak dan kewajiban, sehingga sebuah ikatan perkawinan mempunyai dampak kultural, sosial dan hukum. ${ }^{1}$ Karena pentingnya

1 Muchsin, Hukum Islam dalam Perspektif dan Prospektif (Surabaya: Al-Ikhlas, 2003), hlm. 52. 
Eka Susylawati, dkk.

pengaturan perkawinan maka lahirlah Undang-undang Nomor 1 tahun 1974, yang merupakan tuntutan masyarakat Indonesia. ${ }^{2}$

Eksistensi peradilan di suatu negara merupakan suatu yang mutlak ada. Tugas utama peradilan adalah memberikan putusan atas perkara yang diajukan masyarakat. Peradilan agama sebagai salah satu lingkungan peradilan di Indonesia mempunyai berwenang menyelesaikan suatu perkara sebagaimana diatur dalam pasal 49 Undang-undang Nomor 7 tahun 1989 (telah diubah dalam Undangundang Nomor 50 Tahun 2009). Salah satu kewenangan tersebut adalah menyelesaikan sengketa perkawinan dan hal-hal yang berkaitan dengan sengketa perkawinan, termasuk perkara perceraian.

Masalah perkawinan yang pelik dan sering terjadi di masyarakat adalah perceraian. Dalam hukum Islam, perceraian adalah hal yang diperbolehkan. Namun walaupun diperbolehkan dalam Islam perceraian hendaknya dilakukan dalam suatu keadaan, yang jalan lainnya untuk memperbaiki kehidupan suatu rumah tangga tidak mungkin tercapai.

Perceraian adalah putusnya hubungan suami dan istri dengan alasan-alasan yang cukup melalui pengadilan. Perceraian dapat diajukan oleh suami (cerai talak) maupun oleh istri (cerai gugat). Permohonan cerai talak atau pun cerai gugat dapat dikumulasikan dengan permohonan soal penguasaan anak, nafkah anak, nafkah istri, dan harta bersama atau sesudah ikrar talak diucapkan (sesudah putusan perceraian memperoleh kekuatan hukum tetap).

Kewenangan absolut pengadilan agama dalam sengketa perkawinan tidak hanya menyelesaikan masalah perceraian semata, namun termasuk dalam sengketa yang berkait erat dengan hal-hal sebagai akibat putusnya suatu perkawinan, yaitu: (1) mantan suami dan istri wajib memelihara dan mendidik anak-anaknya dan jika terjadi perselisihan, maka pengadilan yang menetapkan; (2) mantan suami tetap bertanggung jawab atas semua biaya pemeliharaan dan pendidikan anaknya, dan jika suami tidak mampu maka pengadilan dapat memutuskan agar mantan istri ikut serta menanggung biayanya; (3) pengadilan dapat mewajibkan kepada mantan suami

2 Mura P. Hutagalung, Hukum Islam dalam Era Pembangunan (Jakarta: Ind. Hill. Co, 1990), hlm. 70 
untuk menanggung biaya hidup dan atau menentukan sesuatu kewajiban bagi mantan istrinya.

Dalam perkara cerai talak, pada umumnya pengadilan agama selain memutus perkara pokoknya, juga mewajibkan untuk membayar nafkah bagi anak dan istri. Hal ini sangatlah berbeda dengan penerapan putusan, karena pemenuhan kewajiban suami tidak selamanya berjalan baik. Putusan pengadilan agama yang mewajibkan suami membayar nafkah istri tersebut terkadang diabaikan.

Setiap putusan pengadilan idealnya dipatuhi dan dilaksanakan secara suka rela oleh suami. Pemenuhan kewajiban memberi nafkah ini sangatlah tergantung pada i'tikat baik suami. Dalam praktik, apabila istri tidak memperoleh hak nafkahnya, biasanya akan melaporkan hal tersebut ke pengadilan agama. Namun upaya tersebut pada umumnya tidak dapat langsung terealisasi, karena pengadilan hanyalah sebatas melakukan upaya persuasif, yakni memberikan teguran saja.

Hukum acara yang berlaku memberikan jalan yang harus ditempuh oleh istri untuk menuntut hak nafkah sebagaimana putusan pengadilan, yaitu dengan permohonan eksekusi. Upaya eksekusi tersebut akan bermakna jika istri mengajukan permohonan upaya paksa ke pengadilan yang memutus perkara perceraian.

Berdasarkan pengalaman, eksekusi putusan pengadilan atas harta bersama lebih mudah dibandingkan dengan pemenuhan hak nafkah. Banyak sekali kasus pasca perceraian di mana istri tidak mendapatkan nafkah, walaupun hal tersebut sudah diputus oleh pengadilan. Hal inilah yang sering menimbulkan pertanyaan tentang nilai "kepastian hukum" putusan pengadilan agama.

Keinginan untuk memerkarakan kembali atas kelalaian suami terkendala oleh nilai nafkah yang tidak besar nilainya jika dibandingkan dengan biaya yang harus dikeluarkan untuk permohonan eksekusi. Akibatnya, mantan istri seringkali enggan untuk menuntut kewajiban pemenuhan hak-haknya sehingga hakhak tersebut tidak lebih "sebatas di atas kertas". Hal ini ironis karena hak seorang istri yang sudah dijamin oleh hukum materiil dan telah tegas dinyatakan dalam putusan pengadilan yang bersifat inkracht 
Eka Susylawati, dkk.

dan eksekutorial ${ }^{3}$ seringkali tidak ada artinya karena tidak dapat direalisasikan.

Berdasarkan latar belakang masalah di atas, fokus dalam kajian ini adalah: Pertama, bagaimana pelaksanaan putusan nafkah istri pasca putusan cerai talak di pengadilan agama Pamekasan. Kedua, bagaimana penyelesaiannya jika nafkah istri pasca putusan cerai talak tidak dilaksanakan oleh suami.

Kegunaan penelitian bagi lembaga legislatif, tim pembaruan hukum perkawinan, dan tim perumus pembaruan hukum acara peradilan agama adalah diharapkan dapat memberikan fakta bahwa banyak persoalan-persoalan hukum di dalam masyarakat yang belum sepenuhnya memberikan keadilan, sehingga sangat urgent apabila perumus undang-undang mereformulasi hukum perkawinan, khususnya pada pemenuhan nafkah istri pasca perceraian. Bagi pengadilan agama, khususnya kepada hakim yang memutus perkara perceraian, penelitian ini diharapkan akan memberi masukan agar putusan perkara perceraian tidak hanya bernilai kepastian hukum, tetapi juga bernilai keadilan dan kemanfaatan. Bagi dosen dan mahasiswa program studi al-Ahwal al-Syakhshiyah Sekolah Tinggi Agama Islam (STAIN) Pamekasan, penelitian merupakan bahan kajian untuk membandingkan antara law in book dan law in action, yang bertujuan untuk memperkaya khasanah keilmuan.

\section{Metode Penelitian}

Penelitian ini menggunakan pendekatan analisis deskriptif kualitatif, yaitu dengan menggambarkan kasus-kasus implementasi nafkah istri pasca perceraian dan dibandingkan dengan teori yang ada. Data yang disajikan adalah dalam bentuk verbal bukan berbentuk angka, yang semaksimal mungkin berusaha mengungkapkan realitas asli. Pendekatan tersebut dipadukan dengan rancangan penelitian hukum sosiologis (socio legal design), atas proses persidangan, putusan perkara perceraian, dan pelaksanaan putusan. Dengan rancangan penelitian tersebut diharapkan diperoleh

\footnotetext{
3 Bersifat inkracht artinya putusan hakim yang telah bersifat hukum tetap dan apabila pihak terhukum tidak mau melaksanakan isi putusan secara sukarela, maka dapat dilaksanakan dengan paksa oleh pengadilan yang memutusnya. Lihat Sulaikin Lubis, Hukum Acara Perdata Peradilan Agama di Indonesia (Jakarta: Prenada Media, 2005), hlm. 156.
} 
fenomena yang sebenarnya. 4 Peneliti hadir dan terlibat secara langsung dalam setting penelitian dan peneliti bertindak sebagai instrumen penelitian dan sebagai pengumpul.

Jenis data dalam penelitian ini meliputi catatan lapangan (transkrip) dari kegiatan wawancara, pengamatan, dan putusan perceraian di pengadilan agama Pamekasan. Penentuan sampel dilakukan dengan tehnik purposive sampling5. Data tersebut diambil secara sengaja sesuai dengan kebutuhan. ${ }^{6}$ Analisis data penelitian dilakukan dilakukan dengan menggunakan content analysis sehingga diharapkan diperoleh gambaran faktual yuridis tentang implementasi nafkah istri pasca putusan cerai talak di Pengadilan Agama Pamekasan.

Sumber data dalam penelitian ini dibagi ke dalam 2 (dua) kategori, yaitu data primer dan data sekunder. Sumber data primer diperoleh dari hakim dan panitera pengadilan agama, advokat serta suami istri yang bercerai dengan alasan cerai talak. Sumber primer lain yang tidak kalah pentingnya adalah data dari beberapa putusan cerai talak, yang di dalamnya juga diputus dengan kewajiban suami membayar nafkah istri. Sedangkan data sekunder merupakan data kelengkapan dari data primer, yaitu membaca, memahami, dan sekaligus membandingkan dengan peraturan perundang-undangan yang berkait dengan hak nafkah istri pasca cerai talak.

\section{Hasil Penelitian dan Pembahasan}

Di dalam penelitian ini, penulis meneliti 2 (dua) putusan Pengadilan Agama Pamekasan tentang cerai talak yang telah mempunyai kekuatan hukum tetap (inkracht). Data dari putusan pengadilan agama ini akan menjadi bahan wawancara baik dengan suami atau istri, hakim maupun advokat dalam rangka mengetahui tentang kewajiban membayar nafkah bagi istri oleh suami pasca putusan cerai talak.

a. Putusan Cerai Talak No. 0209/Pdt.G/2011/PA. Pmk

\footnotetext{
4 Dimyati M, Penelitian Kualitatif: Paradigma, Epistimologi, Pendekatan Metode dan Terapan (Malang: IPTI dan PPS UM, 2000), hlm. 34.

5 Soerjono Soekamto, Pengantar Penelitian Hukum (Jakarta: Universitas Indonesia Press, 2004), hlm. 12.

6 Suharsimi Arikunto, Prosedur Penelitian: Suatu Pendekatan Praktik (Jakarta: Rineka Cipta, 1996), hlm. 127.
} 
Eka Susylawati, dkk.

Pemohon 21 tahun, swasta, bertempat tinggal di Sampang, mengajukan cerai talak terhadap istrinya yang berumur 20 tahun, pekerjaaan swasta dan bertempat tinggal di Pamekasan.

Dalil perceraian yang diajukan adalah karena dalam perkawinan mereka tidak dikaruniahi keturunan sehingga dalam perkawinan sering terjadi perselisihan dan pertengkaran terus menerus yang tidak dapat didamaikan dan pemohon pulang ke rumah oang tuanya.

Jawaban termohon dalam persidangan adalah membenarkan bahwa dalam rumah tangganya sering terjadi pertengkaran dan peselisihan dan tidak keberatan untuk dicerai oleh pemohon dengan menuntut nafkah iddah sebesar Rp 1.000.000 (satu juta rupiah)

Dalam jawabannya, pemohon menyanggupi permintaan termohon tentang nafkah iddah sebesar Rp 1.000.000 (satu juta rupiah) dan majelis hakim menilai bahwa kesangggupan pemohon tersebut adalah sudah layak. Dalam diktumnya, Pengadilan Agama Pamekasan memutuskan mengabulkan gugatan pemohon, menjatuhkan talak satu ba'in sughra dengan termohon serta menghukum pemohon membayar nafkah iddah kepada termohon sebesar Rp 1.000.000 (satu juta rupiah).

Catatan peneliti dalam putusan cerai talak tersebut adalah tidak terdapat persoalan dalam masalah nafkah isteri pasca cerai talak, karena tuntutan besaran nafkah yang dituntut oleh istri disanggupi oleh suami untuk membayar. Ini artinya bahwa kedua belah pihak sudah sepakat sehingga hakim memutuskan sesuai dengan keinginan pihak-pihak. Hal ini sesuai dengan dengan azas dalam hukum perdata bahwa hakim tidak boleh memutus lebih dari pada yang diminta, walaupun sebenarnya istri masih dapat menuntut lebih dari apa yang diminta, misalnya menuntut Rp 3.000.000 atau menuntut nafkah-nafkah lain sebagaimana yang diatur dalam Undang-Undang Perkawinan atau pun dalam Kompilasi Hukum Islam.

b. Putusan cerai talak No. 0209/Pdt.G/2011/PA.Pmk

Pemohon 36 tahun, pekerjaan wiraswasta bertempat tinggal di Pamekasan, mengajukan cerai talak terhadap istrinya yang berumur 21 tahun, pekerjaan honorer bertempat tinggal di Pamekasan. 
Dalil yang diajukan bahwa walaupun perkawinan telah berlangsung selama 14 tahun dan dikaruniahi seorang anak yang berumur 10 tahun, antara keduanya sering terjadi perselisihan dan pertengkaran karena termohon sering cemburu kepada pemohon tanpa sebab yang jelas. Termohon juga sering menghilangkan barang barang pemohon dan termohon pulang ke rumah orang tuanya tanpa pamit ke rumah orang tuanya dan pisah selama 1,5 bulan.

Dalam Jawabannya, termohon menyatakan secara tertulis bahwa tidak benar bahwa termohon cemburu dan tidak benar bahwa termohon telah menghilangkan barang barang milik pemohon. Yang benar bahwa termohon selama 16 bulan tidak pernah diajak bicara apalagi tidur bersama selama 16 bulan. Atas tindakan pemohon tersebut termohon menuntut ganti rugi nafkah batin tiap harinya $\operatorname{Rp} 50.000 \times 16$ bulan $=R p 24.000 .000$ (duapuluh empat juta rupiah).

Pemohon menyampaikan repliknya bahwa tidak benar termohon tidak diajak bicara dan tidak tidur bersama selama 16 bulan karena pemohon adalah laki laki normal dan pemohon tidak mampu untuk membayar Rp 24.000.000 (duapuluh empat juta rupiah) karena penghasilan pemohon tiap harinya tidak mencapai Rp 50.000 (limapuluh ribu rupiah)

Majelis hakim secara ex officio mempertimbangkan dan memutuskan nafkah madliyah, nafkah iddah dan nafkah mut'ah sesuai dengan pasal 34 ayat 1 Undang-undang Nomor 1 Tahun 1974 jo pasal 80 ayat 4 Kompilasi Hukum Islam yang keseluruhannya merupakan kewajiban melekat bagi seorang suami yang menceraikan istrinya, maka dipandang sanggup dan wajar sesuai pekerjaan pemohon dan kehidupan standar di wilayah Kabupaten Pamekasan yakni nafkah madliyah sebesar Rp 1.800.000 (Rp 15.000 x 4 bulan), nafkah iddah sebesar Rp 900.000 dan mut'ah sebesar Rp 1.000.000.

Catatan peneliti dalam putusan cerai talak tersebut lebih rumit dibandingkan dengan contoh perkara pertama di atas. Hal ini disebabkan istri tidak menuntut nafkah pada umumnya sebagaimana yang diatur dalam perundang-undangan, yakni nafkah batin Rp 50.000 dikalikan selama 16 bulan $=R p 24.000 .000$ dan 
Eka Susylawati, dkk.

suami/pemohon menyatakan tidak sanggup karena penghasilan setiap harinya tidak sampai Rp 50.000 perhari.

Dalam putusan ini majelis hakim menggunakan kebijaksanaannya dengan tidak memutus tentang nafkah batin melainkan memutus nafkah iddah, madliyah dan mut'ah. Nominal yang diputuskan oleh hakim disesuaikan dengan pertimbangan dan kebijaksanaan.

Pengamatan (observasi) merupakan salah satu instrumen yang digunakan dalam penelitian ini, yakni dengan mengamati proses persidangan dalam perkara cerai talak di Pengadilan Agama Pamekasan dan di luar persidangan. Dengan observasi ini nantinya dapat memperkuat data yang diperoleh melalui wawancara maupun dokumentasi.

a. Observasi di persidangan Pengadilan Agama Pamekasan

Budi 38 tahun, swasta bertempat tinggal di Pamekasan, telah menceraikan istrinya yang berumur 25 tahun dengan alasan antara keduanya sudah tidak ada kecocokan sehingga sering terjadi pertengkaran yang berkepanjangan dan menyebabkan termohon pulang ke rumah orang tuanya.

Di persidangan istri menuntut nafkah sebesar Rp 12.000 .000 (duabelas juta rupiah) dan harus dibayar sebelum putusan dijatuhkan. Di persidangan pemohon menyatakan tidak sanggup membayar sebesar tuntutan karena pemohon mempunyai pekerjaan yang tidak tetap.

Majelis hakim memutuskan perkara cerai talak tersebut dengan menghukum pemohon untuk membayar nafkah sebesar Rp 1.500.000 (satu juta limaratus ribu rupiah). Namun ternyata pemohon masih berat untuk membayar nafkah istri dan mejelis hakim memberi waktu agar nafkah tersebut dibayar sebelum pembacaan ikrar talak.

b. Observasi di luar sidang pengadilan

Penulis mengamati secara langsung bahwa pada waktu akan dimulai pembacaan ikrar talak pemohon masih berat untuk membayar nafkah sebesar Rp 1.500 .000 (satu juta limaratus rupiah) sebagaimana yang telah diputus oleh hakim. Namun atas saran dari keluarganya dengan harapan agar perkara tersebut segera tuntas, maka sejumlah uang tersebut diberikan kepada istrinya melalui perantaraan kerabat mantan istri. Menurut pemohon, 
orang-orang di kampungnya jika bercerai dengan istrinya tidak perlu membayar apa-apa terlebih karena penyebab perceraian ini karena kesalahan istrinya yang pulang ke rumah orang tuanya tanpa pamit.

Masalah yang sering berkait dengan perceraian adalah eksistensi dari istri untuk kehidupan yang berikutnya. Kedudukan istri adalah masalah yang senantiasa menjadi perbincangan sepanjang masa, termasuk dalam kedudukannya dalam perkawinan. Posisi istri sering rumit jika hendak dicerai oleh suaminya karena kenyataannya terkadang karena keinginan untuk kawin lagi dengan perempuan lain seorang suami ingin menceraikan istrinya dengan alasan-alasan yang dibuat-buat sehingga sering terjadi pertengkaran dan berakhir dengan perceraian.

Undang-undang Nomor 1 Tahun 1974 tentang Perkawinan dan Kompilasi Hukum Islam (KHI) telah mengatur secara detail tentang perlindungan terhadap istri, hak dan kedudukan yang seimbang dengan kedudukan suami dalam rumah tangga dan pergaulan masyarakat. Namun kenyataannya ketika terjadi perceraian, putusan pengadilan hakim tidak selamanya berpihak pada perlindungan hak istri.

Berdasarkan 149 KHI bilamana perkawinan putus karena cerai talak maka mantan suami wajib memberikan mut'ah yang layak kepada istrinya berupa uang atau benda kecuali mantan istrinya qabl al-dukhul, memberikan nafkah, maskan (tempat tinggal), kiswah, melunasi mahar yang terhutang dan memberikan hadlanah kepada anak-anaknya yang belum dewasa.

Dalam putusan cerai talak selalu diikuti dengan kewajiban untuk memberikan nafkah kepada istri. Untuk adanya putusan nafkah istri harus dengan kehadiran istri di persidangan dan menuntut hak-haknya. Pada umumnya, jika terjadi perselisihan mengenai jumlah yang harus dibayar suami maka dianjurkan untuk diselesaikan secara musyawarah dan kekeluargaan. Jika dengan musyawarah tidak tercapai maka pengadilan agama dapat menentukan jumlahnya yang disesuaikan dengan kemampuan suami.

Akhir dari proses persidangan adalah putusan. Putusan adalah pernyataan hakim sebagai pejabat negara yang diucapkan 
Eka Susylawati, dkk.

dalam persidangan dan bertujuan untuk mengakhiri suatu perkara. ${ }^{7}$ Putusan dapat dilaksanakan secara sukarela atau secara paksa dengan menggunakan alat negara apabila pihak suami tidak mau melaksanakan secara sukarela. Pelaksanaan putusan secara paksa untuk merealisasikan nafkah istri termasuk dalam eksekusi riil. 8 Eksekusi riil akan dilaksanakan oleh pengadilan setelah istri mengajukan permohonan eksekusi.

Peradilan agama merupakan salah satu pelaksana kekuasaan kehakiman mempunyai tugas pokok untuk menerima, memeriksa, dan mengadili serta menyelesaikan setiap perkara yang diajukan guna menegakkan hukum dan keadilan.

Benar dan adilnya penyelesaian suatu perkara perdata di pengadilan bukanlah semata-mata terletak pada putusan yang akan dijatuhkan oleh majelis hakim, namun haruslah dilihat dari sejak awal proses yakni pendaftaran perkara sampai pada pelaksanaan putusan. Dalam hukum acara dikenal due process of law atau undue process. Jika sejak awal sampai putusan sesuai dengan hukum maka sudah dapat dikategorikan memenuhi due process law, sebaliknya jika ada suatu proses yang tidak dipenuhi maka dikategorikan sebagai undue process of law. ${ }^{9}$

Salah satu problematika yang muncul bahwa walaupun dalam suatu perkara perdata sudah sesuai dengan due process of law tersebut, ternyata putusan pengadilan terkadang tidak dapat dilaksanakan sehingga tidak memberikan keadilan bagi pihak-pihak. Hal ini sering terjadi pada pelaksanaan putusan (eksekusi). ${ }^{10}$ Untuk merealisasikan memerlukan upaya paksa (execution force) dari pengadilan.

\footnotetext{
7Abdullah, Pertimbangan Hukum Putusan Pengadilan (Sidoarjo: Pascasarjana Universitas Sunan Giri, 2008), hlm. 47.

8 Wujud dari eksekusi riil (nyata) antara lain eksekusi yang menghukum pihak yang dikalahkan untuk membayar sejumlah uang (pasal 196 HIR), eksekusi putusan yang menghukum orang untuk melakukan sesuatu (pasal $225 \mathrm{HIR}$ ) dan putusan hakim yang memerintahkan pengosongan benda tetap kepada orang yang dikalahkan. Eksekusi riil yang berkait dengan pemenuhan nafkah mantan istri adalah eksekusi yang menghukum pembayaran sejumlah uang. Lihat Abdul Manan, Penerapan Hukum Acara Perdata di Lingkungan Peradilan Agama (Jakarta: Prenada Media Group, 2008), hlm. 314.

9 Ibid., hlm. 313.

10 Ibid.
} 
Dalam praktik, putusan perceraian yang berkait dengan nafkah istri antara cerai talak dan cerai gugat terkadang berbeda. Dalam cerai gugat, pengadilan tidak selamanya akan memberikan putusan tentang nafkah karena ketika istri yang mengajukan gugat cerai dapat kehilangan hak-haknya. Hal ini berbeda dengan cerai talak di mana hakim akan selalu memberikan nafkah tersebut selama dituntut oleh istri dan istri tidak termasuk dalam kategori nusyûz.

Dalam penelitian ini selain data yang diperoleh dari observasi dan dokumentasi di atas, teknik wawancara merupakan teknik yang terpenting dalam penggalian data di lapangan sekaligus untuk melakukan pengecekan atas data yang ada. Berdasarkan data yang dari Panitera Sekretaris Pengadilan Agama Pamekasan bahwa dalam sepuluh tahun terakhir prosentase jumlah cerai talak masih lebih banyak perceraian yang disebabkan cerai gugat (diajukan oleh istri). ${ }^{11}$ Keadaan ini berbeda apabila dibandingkan dengan tahun sebelum 1990 an di mana masih banyak masyarakat yang beranggapan bahwa yang berhak mengajukan perkara perceraian adalah suami saja. Hal ini antara lain disebabkan para istri sudah mulai mengerti akan hak haknya dan problem di masyarakat sangat kompleks sehingga suami sebagai kepala keluarga yang berkewajiban memberikan nafkah pada anak istrinya tidak selamanya dapat direalisasikan sehingga istri tidak terima dan ujung ujungnya terjadi perselisihan yang berakhir dengan perceraian di pengadilan agama.

Cerai talak yang diajukan oleh suami dengan alasan-alasan nantinya akan diuji di pengadilan. Namun 80 persen perkara perceraian diputus secara verstek, yakni diputus dengan tidak dihadiri oleh pasangannya. ${ }^{12}$ Fenomena perkara perceraian tidak dihadiri oleh pesangannya merupakan hal yang lazim. Hal ini disebabkan masyarakat tidak ingin berlama lama dalam proses persidangan.

Dalam perkara cerai talak yang diputus secara verstek menimbulkan masalah, yakni tidak terakomodasinya hak-hak dari mantan istri dan istri tidak dapat membela kepentingannya untuk memperjuangkan hak-haknya, misalnya nafkah walaupun setelah

11 Wawancara dengan Panitera Sekretaris Pengadilan Agama Pamekasan, tanggal 27 Juni 2011

12 Wawancara dengan Wakil Panitera Sekretaris Pengadilan Agama Pamekasan, tanggal 27 Juni 2011 
Eka Susylawati, dkk.

perkara perceraiannya diputus istri masih dapat menuntut nafkah dengan mengajukan gugatan baru, yakni gugatan tuntutan nafkah. Inilah yang kemudian menimbulkan kesan bahwa istri benar-benar "ditinggal begitu saja" oleh suami. Hilangnya hak-hak dari istri tersebut oleh pengadilan karena istri dianggap tidak menuntut apa pun. Padahal kenyataannya di masyarakat ketidakhadiran istri ke pengadilan lebih sering diakibatkan oleh rendahnya pendidikan atau faktor budaya malu hadir ke pengadilan ketika dicerai oleh suaminya.

Ketika istri hadir ke persidangan cerai talak dan mengerti akan hak-haknya maka biasanya akan menuntut nafkah. Tuntutan nafkah akan lebih terperinci dan biasanya dalam jumlah yang sangat besar apabila jika istri menggunakan jasa advokat.

Pada umumnya hakim akan memberikan nafkah iddah pada istri atau pun hak hak lainnya pada perkara perceraian yang diajukan oleh pihak suami karena bagi hakim hal ini merupakan amanat undang undang dan juga rasa kemanusiaan. Diberikannya hak nafkah tersebut jika istri menuntut nafkah kepada suami di persidangan. Namun ada kalanya istri tidak menuntut nafkah. Hal ini biasanya disebabkan istri malas atau enggan karena keangkuhannya atau pun karena ketidakmengertiannya bahwa dirinya dapat menuntut nafkah tersebut pada saat perkara perceraian berlangsung.

Tuntutan nafkah haruslah dituntut oleh istri di depan persidangan baik secara lisan ataupun tertulis. Pada umumnya jika istri tidak memahami akan haknya maka hakim biasanya akan menawarkan pada istri dengan bahasa yang halus, misalnya dengan pertanyaan: "Bu, apakah sampeyan tidak mau menuntut nafkah dari suami? Dan ketika istri menjawab "ya", maka hakim pada putusannya akan memberikan nafkah yang besarnya akan ditentukan oleh majelis hakim. Hal ini terjadi karena dalam realitas tidak jarang istri dalam persidangan hanya diam saja sehingga perlu dipancing dengan pertanyaan tersebut.

Salah satu azas dalam hukum acara perdata adalah hakim bersifat pasif artinya pihak-pihak yang harus aktif dalam persidangan. Sikap hakim yang menawarkan tuntutan nafkah pada istri terkesan bertentangan dengan hukum acara perdata. Tindakan hakim yang aktif tersebut dilakukan oleh hakim ketika istri tidak menyadari hak-haknya sehingga perlu dipancing dan putusan yang dihasilkan nantinya akan lebih adil, terutama pada pihak istri. 
Hak nafkah bagi istri merupakan hal yang lumrah karena tidak jarang istri yang nantinya akan memelihara anak. Seringkali dalam putusan hakim memutuskan jumlah tidak sesuai dari apa yang diminta, misalnya hanya memutus seperenamnya. Pihak istri sebenarnya tidak menerima, namun mereka pada umumnya pasrah. Padahal penyebab perceraian tersebut terkadang disebabkan oleh suami yang tidak bertanggung jawab kepada keluarga ataupun kawin lagi.

Majelis hakim dalam memutuskan besaran nafkah untuk istri mendasarkan kepada tingkat ekonomi suami dan tingkat perekonomian yang ada pada masyarakat Pamekasan. Hal itulah yang menyebabkan pengetahuan dan keyakinan majelis hakim sangatlah berperan dalam menentukan dan memutuskan besarnya nafkah yang akan dibebankan kepada suami. Hal ini terjadi apabila terjadi perbedaan antara permohonan nilai yang diajukan oleh istri dan tingkat kemampuan ekonomi suami.

Putusan tentang nafkah untuk istri seringkali tidak sesuai dengan harapan dan keinginan istri. Hal ini disebabkan kadangkala istri menuntut nafkah karena terdapat sesuatu yang tejadi ketika perkawinan masih harmonis, misalnya seorang istri menuntut nafkah Rp 5.000.000 (lima juta rupiah) untuk menutupi hutang rumah tangga.13 Hutang tersebut untuk modal menanam tembakau tahun sebelumnya dan hingga proses perceraian belum dibayar, atas hak tersebut hakim hanya memberikan nafkah Rp 1.500.000 (satu juta limaratus ribu rupiah). Sebenarnya istri berkeinginan memrotes kepada majelis hakim, namun setelah dipikir lebih lanjut niat tersebut diurungkan karena dianggap tidak akan mengubah keadaan.

Menurut keterangan seorang hakim menyatakan bahwa sebenarnya majelis hakim berkenginan memutuskan dengan nilai yang maksimal sesuai dengan harapan istri. Namun hak tersebut tidak dapat dilakukan ketika mendasarkan pada pada tingkat ekonomi dan pekerjaan suami yang pas-pasan, sehingga misalnya hakim memutus dengan sesuai permintaan suami dan suami tidak mampu maka konsekuensinya akan sama saja, yakni tidak akan terealisasi.

13 Wawancara dengan $\mathrm{AKH}$, ibu rumah tangga, 26 tahun bertempat tinggal di desa Larangan Tokol Kecamatan Tlanakan, tanggal 30 Juni 2011 
Eka Susylawati, dkk.

Peneliti juga menemukan fakta bahwa terkadang suami dan istri sudah sepakat untuk menentukan besaran nafkah yang akan dibayar oleh suami. Hal ini pernah ditemukan pada seorang istri yang sepakat tidak akan menuntut apa pun, termasuk nafkah kepada suami dengan syarat harta gono gini (harta bersama selama perkawinan) diberikan kepada anak.

Menurut penuturan seorang hakim, pada tahun 1990 seorang suami yang statusnya Pegawai Negeri Sipil memiliki kewajiban untuk memberikan 1/3 gajinya kepada anak dan 1/3 untuk istri. Namun akhir-akhir ini jarang diterapkan di pengadilan agama. Hal ini disebabkan jika putusan ini dibebankan pada suami, maka akan memberatkan suami karena hanya menerima $1 / 3$ dari gaji. Ini akan lebih memberatkan lagi apabila suami kawin lagi pasca perceraian, maka kehidupan rumah tangga suami tidak akan layak. ${ }^{14}$

Problem lainnya, apabila suami enggan untuk membayar nafkah sebagaimana yang ditetapkan oleh putusan pengadilan agama. Banyak faktor yang menyebabkan suami enggan membayar, antara lain masih terdapat anggapan di masyarakat bahwa cerai talak adalah hak mutlak suami sehingga suami juga memiliki hak mutlak untuk membayar atau tidaknya nafkah yang ada dalam putusan. Terkadang suami sangat membenci istri, sehingga malas tuntuk membayar nafkah.

Ketika hakim memutuskan sejumlah nafkah pada istri dan suami tidak mau membayar, maka akibat negatif akan dirasakan istri karena tidak terealisasi hak-haknya. Majelis hakim ketika memutus suatu perkara cerai talak yang dalam salah satu diktumnya membebani suami untuk membayar nafkah akan memberitahukan kewajiban hal tersebut kepada suami. Pada umumnya pengadilan akan memberi waktu selama 6 bulan untuk menunda ikrar talak sebelum nafkah tersebut dibayar oleh suami. Dalam praktik, cara ini cukup efektif untuk memaksa suami untuk membayar.

Ketika ikrar talak ditunda pada umumnya suami baik secara sukarela maupun terpaksa berusaha membayar nafkah kepada istri. Dalam kenyataan di masyarakat pada umumnya suami akan segera membayar ketika berniat untuk segera kawin lagi.

14 Wawancara dengan Drs. H. Ali Ridho, Hakim Pengadilan Agama Pamekasan, tanggal 4 Juli 2011 
Masalah timbul jika ternyata suami yang oleh pengadilan sudah dibebani membayar nafkah tetapi tetap tidak mau membayar walaupun sudah diberikan waktu 6 (enam) bulan oleh hakim. Dalam praktik, seandainya lebih dari 6 bulan ternyata suami belum memberikan nafkah, maka pengadilan tidak dapat menolak permintaan untuk menyatakan ikrar talak karena dalam aturan perundang-undangan tidak mengatur hal tersebut.

Adapun upaya hukum yang dapat dilakukan oleh istri ketika nafkahnya tidak dibayar adalah dengan jalan mengajukan eksekusi. Hal ini sesuai dengan HIR maupun undang-undang peradilan agama yang mengatur tentang pelaksanaan putusan pengadilan. Memang eksekusi nafkah cukup rumit jika dibandingkan dengan eksekusi harta bersama. Pengajuan eksekusi atas nafkah yang telah diputus oleh hakim jarang sekali terjadi di Pengadilan Agama Pamekasan. Hal ini disebabkan nilai nafkah yang diputus oleh hakim tidak begitu besar. Kalaupun dimohon eksekusi terdapat kesulitan baik secara yuridis dan teknis. Secara yuridis, di dalam gugatan perceraian hampir tidak pernah ditemukan ada yang di dalam petitum-nya minta agar harta kekayaan suami dijadikan sita jaminan. Hal ini akan menyulitkan tentang benda apa yang akan disita ketika pelaksanaan eksekusi.

Menurut pendapat penulis, dibandingkan dengan di Malaysia, proses perceraian di Indonesia lebih mudah, terutama bagi suami yang mengajukan cerai talak. Di Malaysia jika suami akan menceraikan istrinya, maka ia terlebih dahulu harus menyiapkan segala jenis nafkah sehingga jika perkara perceraiannya diputus oleh pengadilan, pihak isteri akan langsung menerima nafkah terebut. Berdasarkan uraian di atas tampak bahwa kedudukan isteri yang telah memperoleh hak nafkah berdasarkan putusan pengadilan belumlah sepenuhnya memperoleh perlindungan di mata hukum. Apabila suami yang akan menceraikan isterinya dengan secara sadar dan tanggung jawab memberikan nafkahnya, maka hal tersebut merupakan sesuatu yang ideal. Namun yang terjadi di masyarakat berlaku yang sebaliknya, isteri yang hanya memperoleh nominal nafkah yang tidak begitu besar dan terkadang harus menunggu nafkah tersebut dibayar oleh suami. Idealnya apabila suami akan menceraikan isterinya, maka terlebih dahulu menyiapkan nafkah yang jumlahnya sudah ditaksir oleh pengadilan dan nafkah tersebut 
Eka Susylawati, dkk.

dititipkan di pengadilan sehingga begitu perkara cerai talak sudah diputus istri akan langsung menerima hak nafkahnya.

Upaya Pengadilan Agama Pamekasan untuk memberikan perlindungan terhadap istri adalah dengan jalan memberikan nafkah telah dilakukan dengan maksimal. Namun upaya tersebut tidak selamanya berjalan mulus, karena pihak suami yang tidak merealisasikannya.

Dalam pasal 34 Undang-undang Nomor 1 Tahun 1974 jo pasal 80 (4) Kompilasi Hukum Islam sudah ditentukan tentang macammacam hak yang dapat dituntut istri ketika dicerai oleh suaminya di pengadilan, misalnya nafkah iddah, nafkah mut'ah, dan sebagainya. Sebagaimana dalam paparan di atas, ternyata tidak semua istri menuntut semua nafkah, melainkan yang dituntut nafkah tertentu saja, misalnya nafkah iddah. Ketika istri menuntut nafkah iddah, maka hakim hanya akan memutus nafkah iddah (putusan nomor 0209/pdt.G/2011/PA.Pmk).

Dalam perkara yang lain, hakim Pengadilan Agama Pamekasan justru memberikan berbagai macam nafkah, padahal nafkah yang dituntut oleh istri adalah nafkah batin (Putusan 0678/Pdt.G/2010/PA.Pmk). Dalam perkara tersebut dengan hanya mendasarkan pada penghasilan suami yang perharinya rata rata Rp 50.000 (limapuluh ribu rupiah), sehingga tidak sanggup membayar nafkah batin yang dituntut yakni Rp 24.000 .000 (duapuluh empat juta rupiah). Hakim memutus nafkah madliyah, nafkah iddah dan nafkah mut'ah yang besarnya Rp 3.700 .000 (tiga juta tujuhratus ribu rupiah).

Problem lainnya dalam pelaksanaan nafkah bagi istri pasca cerai talak adalah tidak langsung dapat direalisasikannya nafkah tersebut setelah putusan. Sebagian suami enggan membayar nafkah bagi istri. Apabila keengganan suami tersebut dibiarkan, maka suatu putusan pengadilan yang menyangkut tentang nafkah istri akan siasia dan putusan tidak lebih dari pepesan kosong.

Salah satu cara untuk memaksa suami agar membayar nafkah istri yang telah diputus pengadilan adalah dengan menunda $i k r a r$ talak. Penundaan ini merupakan salah satu kebijaksanaan hakim dan tidak diatur dalam perundang-undangan dan ternyata penundaan ikrar talak maksimal 6 bulan ini cukup efektif untuk memaksa suami membayar nafkah bagi istrinya. Hal ini dapat dibuktikan bahwa mayoritas nafkah cerai dibayar oleh suami sebelum jangka waktu 6 
bulan. Kebijaksanaan ini merupakan upaya hakim agar putusan memberikan keadilan bagi pihak istri.

Masalah dapat timbul apabila suami paham tentang hukum, karena dalam hukum acara maupun dalam hukum materiil tidak ditemukan aturan yang mengatur tentang penundaan pernyataan ikrar talak apabila suami belum membayar nafkah kepada istri. Artinya apabila suami memaksa ingin mengucapkan ikrar talak padahal belum membayar nafkah, maka hakim tidak dapat menghalanginya. Apabila hal tersebut terjadi, maka salah satu upaya yang dapat dilakukan oleh istri adalah dengan permohonan eksekusi atas putusan nafkah.

Bagi seorang istri yang tidak berpendidikan dan tidak memiliki ekonomi yang mapan, mengajukan eksekusi adalah suatu yang sulit. Selain prosesnya panjang, juga memerlukan biaya yang relatif besar dan mungkin biaya untuk mengajukan eksekusi dengan nominal yang diputus oleh hakim tidaklah dalam nilai yang besar.

Berdasarkan uraian di atas nampak bahwa sebenarnya kedudukan istri yang sudah memperoleh nafkah berdasarkan putusan pengadilan agama belumlah sepenuhnya memperoleh perlindungan di mata hukum. Apabila suami yang menceraikan seorang istri dengan secara sadar dan bertanggung jawab memberikan nafkahnya, maka hal tersebut merupakan suatu yang ideal. Namun terkadang di masyarakat yang berlaku sebaliknya, istri yang hanya memperoleh nominal nafkah yang tidak begitu besar harus menunggu dibayarnya. Idealnya, apabila suami akan menceraikan istrinya haruslah terlebih dahulu menyiapkan nafkah. Dengan jaminan nafkah tersebut akan memberikan nilai positif terhadap suami karena suami dapat segera merealisasikan ikrar talaknya.

\section{Penutup}

Pelaksanaan putusan nafkah istri pasca putusan cerai talak di Pengadilan Agama Pamekasan pada umumnya nafkah istri dibayar oleh suami sebelum pembacaan ikrar talak walaupun dengan nilai nafkah yang tidak relatif besar atau jauh apabila dibandingkan dengan tuntutan istri. Apabila suami tidak dapat memenuhi nafkah yang telah diputus oleh pengadilan agama, maka majelis hakim akan menunda pelaksanaan ikrar talak selama 6 bulan. Apabila dalam 
Eka Susylawati, dkk.

waktu 6 bulan tersebut suami tetap tidak menyatakan tidak mampu untuk membayar, maka pengadilan agama tetap akan memperkenankan suami untuk mengucapkan ikrar talak. Apabila hal ini terjadi, maka istri tidak akan memperoleh nafkah apa pun dari suami.

Dengan demikian maka perlu adanya upaya-upaya sebagai berikut: Pertama, bagi bidang legislatif. Persoalan nafkah bagi isteri yang telah dicerai oleh suami masih belum sepenuhnya memberikan perlindungan hukum kepada istri. Hal ini disebabkan dalam perundang-undangan belum mengatur secara detail tentang bagaimana cara yang tepat agar istri dapat secara langsung menerima hak nafkahnya setelah adanya putusan perceraian. Dengan demikian, sangatlah urgent untuk menyempurnakan aturan perundangundangan yang mengatur tentang nafkah istri. Kedua, bagi hakim pengadilan agama dalam memberikan putusan cerai talak hendaknya menghitung secara lebih rinci dengan memperhatikan kebutuhan istri dan memosisikan sebagai pejabat negara yang otonom, sehingga dalam memberikan putusan lebih mendasarkan pada nilai-nilai keadilan, termasuk masalah nafkah. Ketiga, bagi mahasiswa dan dosen STAIN Pamekasan, idealnya memberi sosialisasi kepada masyarakat tentang hukum perkawinan termasuk hak hak istri pasca perceraian.

Daftar Pustaka

Abdullah. Pertimbangan Hukum Putusan Pengadilan. Sidoarjo: Pascasarjana Universitas Sunan Giri, 2008.

Arikunto, Suharsimi. Prosedur Penelitian: Suatu Pendekatan Praktik. Jakarta: Rineka Cipta, 1996

Dimyati, M. Penelitian Kualitatif: Paradigma, Epistimologi, Pendekatan Metode dan Terapan. Malang: IPTI dan PPS UM, 2000.

Harahap, Yahya. Kedudukan Kewenangan dan Acara Peradilan Agama UU No, 7 Tahun 1989. Jakarta: Sinar Grafika, 2007.

Hutagalung, Mura. Hukum Islam dalam Era Pembangunan. Jakarta: Ind. Hill. Co, 1990.

Lubis, Sulaikin. Hukum Acara Perdata Peradilan Agama di Indonesia. Jakarta: Prenada Media, 2005.

Manan, Abdul. Penerapan Hukum Acara Perdata di Lingkungan Peradilan Agama. Jakarta: Prenada Media Group, 2008. 
Muchsin. Hukum Islam dalam Perspektif dan Prospektif. Surabaya: AlIkhlas, 2003.

Musawwamah, Siti, Taufiqurrahman dan Susylawati, Eka. Fenomena Keberdayaan Istri dalam Mengajukan Gugatan Perceraian di Pengadilan Agama Pamekasan. Laporan Penelitian Kompetitif Kolektif Terpadu, Pusat Studi Wanita STAIN Pamekasan, 2007.

Soekanto, Soerjono. Pengantar Penelitian Hukum. Jakarta: Universitas Indonesia Press, 2004. 